\title{
Boekresensies/Book reviews
}

Kugel, J L 2006. The ladder of Jacob. Ancient interpretations of the biblical story of Jacob and his children. Princeton, NJ: Princeton University Press. ISBN-13:978-0-691-12122-2. £15-95.

James Kugel, currently Director of the Institute for the History of the Jewish Bible at Bar-Ilan University in Israel, is an expert in the history of biblical interpretation and well equipped to write a book that gives the reader an introduction to and explanation of the ancient exegesis of the particular text from Genesis under discussion in this book.

In a narrow sense the title of this book, "The ladder of Jacob" refers to the incident recounted in Genesis 28 concerning a dream Jacob had. In a broader sense the image of a ladder stretching from earth to heaven reminds the reader of the chain of traditions about different Biblical texts, set in the ground and directing us to heaven and the glorification of scripture.

The subtitle of the book "Ancient Interpretations of the Biblical Story of Jacob and his Children" refers to the story in Genesis concerning the ancestors of Israel. To Kugel's mind these are what they are, namely "... etiological narratives and old-time historiography ...” (p.221) and he traces the history of ancient interpretations of these stories.

Chapter One concerns Jacob and the Bible's ancient interpreters and is followed by chapters two to six with as subject matter the ladder of Jacob, the rape of Dinah, and Simeon and Levi's Revenge, Reuben's sin with Bilhah, how Levi came to be a priest and Judah and the trail of Tamar respectively. In the last chapter, Chapter Seven, Kugel concludes with a discussion of "A Prayer about Jacob and Israel from the Dead Sea Scrolls”.

Each chapter starts with a recount of the Biblical story under discussion, followed by an exposition of the most important ancient documents referring to and interpreting the particular Biblical story. It is within these discussions that Kugel's expertise is apparent. From his treatment of the ancient interpreters it is clear that they did not write biblical commentaries in the modern sense of the word, citing the text verse by verse and then providing their own explanation. Ancient interpreters retold the Biblical text in their own words, inserting in their retellings explanations of any difficulties 
found in the Biblical version. According to Kugel these retellings abound in the literature of the "late biblical period, starting from the third century B.C.E. and extending into the first or second century of the common era" (p.37).

The Testament of the Twelve Patriarchs features in every chapter, while numerous other ancient interpreters, to many to list here, are either discussed or revered to. Kugel's knowledge of ancient text and interpreters from this particular period becomes apparent in his discussion and evaluation of these. From Kugel's treatment of the material it becomes clear where certain traditions come from and how it developed over time. Here lies the value of this work, especially for those of us not working on ancient interpreters every day.

The end notes on each chapter are of special value since it elaborates on certain key issues, while it mentions related literature, ancient and modern. For reference purposes the indexes on subjects, the Hebrew Bible and "Motifs Studied" are of great help.

This book can be recommended for every one interested in the development of certain biblical traditions, but especially for those interested in the way ancient interpreters treated biblical texts.

S I Cronjé

Peter Spitaler, Universale Sünde von Juden und Heiden? Eine Untersuchung zu Römer 1,18-3,20 (Forschung zur Bibel Band 109), Würzburg: Echter Verlag, 2006. 223 pp. Price unknown.

This work of Spitaler was accepted as a doctoral dissertation by the Catholic Theological Faculty of the Ludwig-Maximilians University of Münich. According to the author, the commonly accepted exegesis of Romans 1:18-3:20 is conditioned by the apriori that Paul focuses first and foremost on the universality of human sin: Firstly, he portrays in 1:18-32 the sinfulness of mankind in general, or, more specifically, that of the heathen nations, then that of the Jewish people (2:1-3:8) and finally concludes in 3:9-20 with the sinfulness of the human race as a whole. However, this utterly pessimistic view of mankind is not substantiated by the text of Romans 1:18-3:8 (to which 1:16-17 should be added). This section rather reveals a much more positive anthropology. Only in 3:9-20 Paul comes to the point where the whole of humanity is subsumed under the stark reality of universal sin. In 1:18-3:8, Paul operates with the existence of two 
opposing life-styles, which he does not associate with specific ethnoreligious categories (non-Jew - Jew). These two life-styles are those of the dikaioi $(1: 16 ; 2: 7,10,14-15,17 f f, 26,29)$ and the adikoi $(1: 18-$ 32; 2:1ff,8-9,21-24). They indicate that Paul's view of man is far from being one-dimensional; it is in fact multidimensional: among Jews as well as Greeks we find, alongside those practising adikia, also those who are doing good - although all of them are eventually characterized (in 3:9ff) as being under sin. In Spitaler's view, these positive stretches significantly ameliorate the pessimistic anthropology ascribed to Paul by traditional interpretation.

On the positive side the author covers an impressive amount of relevant literature and presents very useful information, particularly in the extensive footnotes. He also convincingly shows that the anthropos of Romans 2:1ff no longer should be understood as a referece to a Jewish critic. The traditional interpretation is due to an illegitimate reading of $2: 1 \mathrm{ff}$ in the light of 2:17ff. Spitaler's discussion of 2:1ff also reaffirms the need to reassess the function of Paul's positive remarks about those practising righteousness, seeking "glory, honour and immortality" and who will eventually receive eternal life $(2: 7,10)$, within the larger picture of universal sin and man's need of salvation.

Unfortunately Spitaler's efforts to substantiate his hypothesis show methodological deficiencies. His main argument fails to convince, due to his questionable exegesis of critical passages. More than once he resorts to an exegetical tour de force. Two examples: In order to illustrate that for Paul there are amongst the Jews also those doing good, he interprets Romans 2:17-20 as a positive assessment. However, within the context of 2:17-24, this reading is strained, if not impossible, since it is quite obvious that in 2:17-20 Paul is constructing a platform to launch an attack on Jewish piety. The most glaring example of a forceful petitio principii is his interpretation of Romans 3:9-10. This is a key pronouncement in which, not without reason, traditional exegesis finds confirmation of its understanding of the development of Paul's argument, namely that Paul sequentially first indicates the sinfulness of non-Jews (1:18-32) and then that of the Jews (2-3:8). The usual translation of 3:9-10 runs more or less as follows: "What then? Are we Jews any better off? No, not at all; for we have already charged (p r oht i a s a meqa) that all men, both Jews and Greeks, are under the power of sin, as it is written ...”. To prove Paul's statement, a long catena of Old 
Testament citations then follows. Realizing that this rendering of 3:9-10 would not only strengthen the main tenet of traditional exegesis, but that it would also be exceedinly detrimental to his own position, Spitaler endeavours to reinterpret Paul's statement, and particularly the verbal form proht ia s a meqa, in such a manner that it changes from a back-reference to what has already been said, to a forward reference to what is to follow. In this way, Paul now only begins his statement that the entire humanity is under sin and in need of redemption. Spitaler's efforts are tortuous indeed. He reads the words "as it is written" as referring to p roht i a a meqa, indicating that Scripture does the actual accusing; but these words undoubtedly refer back to the immediately preceding pronouncement that all Jews and Greeks are under the power of sin. Scripture does not accuse, but proves that the content of Paul's accusation is correct. Despite Spitaler's strenuous efforts, into which I cannot go into further detail, there is no way in which proht ias a meqa, although being a hapax legomenon, can be understood as not referring back to Paul's foregoing argument.. In addition, it almost unthinkable that Paul would introduce an entirely new and crucial pronouncement which subsumes all of mankind under the power of sin, with such a short sentence as the one in 3:9d and then, without any further explanation, bring in such an impressive array of testimonies from Scripture. The obvious understanding would much rather be that Paul, in his foregoing argument, dealt extensively with the guilt of both non-Jews and Jews and now concludes and substantiates his major exposition by means of a correspondingly extensive list of Old Testament quotations. Thus Romans 1:18 to 3:8 as a whole prepares the conclusion presented in 3:9ff. To qualify the former section as being merely a "narrative portrait" and only the latter as a "theological pronouncement" is certainly unwarranted. Another indication that Paul is indeed presenting his point from the perspective of broad ethno-religious categories, is the fact that he actually uses the appelation "Jew" in 2:17, intimating at the same time that he has previously dealt with another (non-Jewish) group (cf 1:18-32). Despite Spitaler's arguments, it is true that idolatry and same-sex practises were more commonly associated with the nonJewish (Greek and Roman) part of mankind than with Jewry. Although 1:18-32 does not exclude Jews in so many words, the focus is on the former. Another questionable aspect of Spitaler's presentation is the unconvincing manner in which he postulates that Romans 1:18-32 and 2:1ff contain allusions to tendencies within 
Roman ecclesiastical circles: 1:18-32 implies a warning against apostacy and 2:1ff against criticizing fellow believers. I can find no trace of this in the relevant texts. Paul is depicting the human condition outside Christ from various wide-ranging perspectives. He certainly addresses inner-ecclesiastical problems elsewhere in Romans, but in this case these problems are not in the picture. The publication also contains numerous orthographical errors.

Andrie du Toit

Hastings A, 2001. A History of English Christianity 1920-2000. London: SCM. 720 + lxi pages. ISBN 033402824 8. Price \$37.50.

Just prior to his death in 2001, Adrian Hastings reworked the text of his history of English Christianity which was first published in 1986 and later reworked and expanded in 1991. This new edition was again reworked ostensibly to extend the period from 1920 until 2000.

The new sections in this edition are the introductory and incisive overview of English Church History in the twentieth century and a section on the 1990s. Hastings claims that this represents a partial attempt at revisionism to make up for earlier deficits in English church history where the secular was emphasized. He established his own parameters and admits the limitation of the work due to the following constraints: quantitatively, the period is extensive so the scope is somewhat limited; the book is based largely on secondary sources; and this is very much a personal view of the period written by an ecumenically minded Roman Catholic with enormous experience of the world church in its African expression.

As a whole Hastings deals with the perennial question in church history concerning the relation of Church and State/society. He discerns five significant movements droning the course of the twentieth century - the ecumenical movement and the emergence of new religious culture in the mid-twentieth century; the impact of Pope John XXIII and Vatican II in the 1960s; the decline in ministerial authority; Church and world - issues of social justice and the changing role of women; and the ending of Protestant domination.

After giving an overview of the period and content, Hastings deals with seven main periods of the twentieth century. In each, he examines the political context of the period before considering the 
Anglican, Roman Catholic and Free Churches in turn. Despite this methodology, Hastings approach is largely ecumenical and acknowledges the overlap which occurred through ecumenical contact with its periods of progress and regress. He situates his church history firmly within the wider English context as is seen from his treatment of the General Strike, the Abdication Crisis, the Second World War, international politics and issues of theology and culture. He also expands the range of his Christian concern by delving into Christian literary work, music and the arts. Despite this approach, he also manages to assess the role and contribution of the leading ecclesiastical figures of the period as exemplars of the trends which emerged from time to time. These are scholars and churchmen whom we have read, but about whom we knew very little.

This book has been described as one of the great classics of modern church history and I would concur. However, Hastings tends to focus rather narrowly on the Church of England's Catholicism to the relative exclusion of the contribution of the Free Churches. Further, since the book is the result of largely secondary sources, it would have been helpful to have had a bibliography appended of these and primary sources. A serious omission is a detailed comment in the 1990s to develop ideas raised in the Introduction. This would have given a more comprehensive and coherent ending to $a$ substantial work of Christian history. Hence, the title is something of a misnomer. Yet, all in all, this book makes a significant contribution to our understanding of English church history in the twentieth century and because it is extremely lucid is a particularly good read!

G A Duncan

Ollig, Hans-Ludwig (Hg.). Theo-Anthropologie. Jörg Splett zu Ehren. Echter: Würzburg. 114p. ISBN 3-429-02809-4 / 978-3-42902809-1. Price: €20-00.

In 2005 Jörg Splett retired as professor in Philosophy at the Philosophisch-Theologischen Hochschule Sankt Georgen, Frankfurt, Germany. He has left behind such an imposing academic contribution and presence, that he was not only honoured on his $65^{\text {th }}$ birthday with a Festschrift in 2001 (Mitdenken über Gott und den Menschen), but also with a Festschrift in 2006 (Ant-wort: Jörg Splett zum 70. Geburtstag) on his $70^{\text {th }}$ birthday. At his retirement in 2005, a symposium was held on his philosophic-theological contribution 
which spanned a period of more than thirty years. The eight papers which were presented at the Symposium on 22 January 2005 as well as Splett's response to these papers, are published in this book with the title Theo-Anthropologie in the series "Religion in der Moderne" (Bd 15). The editor of the publication is his colleague, the philosopher Hans-Ludwig Ollig.

The published papers cover diverse philosophical-theological topics, ranging from a philosophical-theological perspective on the experience of God to the quest for an aesthetics of the Christian faith and even address the question of the legalisation of the torture of terrorists! However, all the contributions deliberately seek in one way or another a point of contact with the "Denkentwurf" of Splett.

In the first paper with the title "Lob des Konkreten. Jörg Spletts Religionsphilosophie der Gotteserfahrung und ihre Tragweite für die christliche Theologie” (page 17-31), the Roman Catholic theologian Peter Hofmann - who had earlier completed his dissertation with Splett - focuses on Splett's understanding of the experience of God from a perspective of the philosophy of religion as well as its implications for a Christian Theology, specifically with regards to the question of determining the "Proprium" of Christian Theology. Hofmann does not intend to carry "Splett-Zitate" to "Sankt Georgen" (see page 18), yet he wishes to proceed along with the thought impulses from Splett. Therefore he firstly explores the historical questions regarding the paradoxical nature of the "initium und principium” of theological reflection (19ff), and moves onto "Erste Philosophie" which seeks - looking backwards - to understand the answer that God has already given us (see page 26: "...Erste Philosophie fragt nach Gott, indem sie Gottes bereits gegebene Antwort zu verstehen sucht”). Secondly he discusses his understanding of the Bible as "Erste Theologie" (see page 29-31). Here and now we are only but speculators, yet we praise God concretely as we reflect on his 'Yes' in Jesus Christ, an affirmation of all his promises.

In his search for a contemporary justification and understanding of post-Kantian metaphysics, Günter Kruck critically discusses Splett's philosophical effort to design a new justification ("Begründung") for metaphysical thinking in the second paper with the title "'Der Wahrheit die Ehre geben'. Ueberlegungen zu einer zeitgemässen Metaphysik im Anschluss an Jörg Splett” (33-42). The core of his re-design (see page 43ff), lies for Kruck in Splett's new 
semantic unfolding of the concept of truth in relation to "honour" ("Ehre") from the awareness of a "lebensspezifischen Grundvollzugs" in which God theoretically becomes recognisable. Kruck however does not only argue that Splett's formulation is an "impertinente Prädikation" (34), but also that his semantic new unfolding of the concept of truth cannot avoid ultimately the accusation of "Projektionsverdacht" (42). Thomas Schmidt focuses on the importance of Hegel's influence on an understanding of the theology of Splett (specifically Splett's dissertation on the doctrine of the Trinity by Hegel). This he explicates in his paper with the title "Gewissheit im Denken. Hegels Begriff der religiosen Ueberzeugung" (43-54) indicating the significance of the concepts "Begreifendes Denken” and "Ueberzeugung” (44), concepts which Splett has taken over from Hegel and which has characterised his understanding of "Gotteserfahrung im Denken". The title of Olivier Wiertz's paper bears the title "Christliche Philosophen als Philosophen der christlichen Gemeinschaft: Alvin Plantingas Konzept christlicher Philosophie” (55-67). Basic questions concern a Christian philosophy: what are the ways and means to address the issue? From the conviction that God created the sensus divinitatis in humans as a most basic premise that needs no justification, Wiertz argues - following Plantinga's understanding of Christian Philosophy and its fourfold task (see 56ff) - that natural Theology forms an important part of and is thus a task of Christian Theology. Moving - in his own words - to a contemporary modern concept, namely aesthetics, Joao Duque's paper with the title " $\mathrm{Zu}$ einer Ästhetik christlichen Glaubens in postmoderner Zeit” (67-78) wrestles with the aesthetic dimensions of being human as the boundary of rationalistic explication of the world (69). Over against modern (67ff) and postmodern (70ff) understandings of Aesthetics, Duque unfolds a Christian Aesthetics from the vantage point of suffering (73ff) and "leiblicher Begegnungen" (76ff) in order to overcome abstract Gnostic constructions of the self. For Duque, the via corporis and the memoria passionis, mortis et resurrectionis represent the "Hauptwege" of a theological Aesthetics (78). From the perspective of practical philosophy, Gerhard Beestermöller addresses the ethical question of the torture of terrorists in his paper with the title "Fallen wir ins Bodenlose? Auf der Suche nach einer tragfähigen Begründung für ein absolutes Folterverbot als letzter Halt einer Anti-Terrorismusethik” (79-89). Taking as vantage point the reports of torture from the Abu Graib Prison in Iraq (79), 
Beestermöller discusses the grounds - following the Hamburger sociologist Jan Philipp Reemtsma (80ff) - against a prohibition of torture ("Foltergebot") and subsequently the grounds - following the catholic theologian Lothar Bendel - for the prohibition of torture (82ff). He argues that the arguments of both Reemtsma and Bendel are inadequate (85ff) and that it is important not only to discuss and clarify the concept "torture" (and requesting Splett to help us along this way!), but also to indicate clearly and specifically why the act of torture is problematic, and what good ("Gut") is destroyed by this very act. In the last contribution, Joerg Fehige's paper with the title "Gotteserfahrung im Denken. Zur Methode des Gedankenexperiments - ein Fall für den Rationalismus” (91-103), gives us an appraisal of the rationalistic implications of the justification of theism by Splett (91ff). In a discussion of the empirical debate between Brown and Norton (94ff), Fehige concludes that this debate clearly illustrates that the objection to reliability as argument against rationalism is not convincing (103).

Under the title "Theo-Anthropologie. Ein Antwortversuch" (105-113), Splett responded to the papers delivered at the Symposium. His response is an excellent example - as Ollig calls it in his introduction (9-16) to the book - of the "Splettsche Disputationskunst" (15) in which the basic conviction of his "Denkentwurf" is clearly proliferated, namely that humans cannot talk properly ("recht") about God if they remain silent about humans, and also that humans cannot talk properly about humans if they remain silent about God. For Splett, this is the most basic task of theologians, namely the explication of a theocentric understanding of reality.

Theo-Anthropologie is an interesting and very readable publication on Splett's philosophical-theological contribution. Of special interest is the fact that most of the contributors have tried either to engage critically with Splett, or to move beyond him, thus stimulating ongoing reflection (with Splett as interlocater) on contemporary issues. This in my opinion is the greatest value of the publication. A few shortcomings of the publication however are to be mentioned: Why is there no information on the contributors? I also think an index - given the range of discussed topics - would have been helpful.

D P Veldsman 
Van Huyssteen, J Wentzel 2006. Alone in World? Human Uniqueness in science and theology. Göttingen: Vandenhoeck \& Ruprecht. ISBN: 3525569777. €49-90.

Originally delivered as the Gifford Lectures the book is a compendium of Van Huyssteen's thoughts on the topic of human uniqueness in science and theology. The invitation to deliver the lectures at the University of Edinburgh in 2004 gave Van Huyssteen the chance to contextualise his previous work in philosophical theology. The crux of this earlier work is found in The Shaping of Rationality: Toward Interdisciplinarity in Theology and Science published by Eerdmans in 1999. It is against this backdrop that Van Huyssteen's appraisal of human "uniqueness" should be understood.

The author is convinced that humans have a unique ability to be rational. This ability to be rational infuses our everyday lives and our involvement with religious faith, as well as our scientific achievements. He therefore rejects the idea that the domains of religious faith and scientific thought are exemplified by opposing notions of rationality. He calls for a postfoundationalist notion of rationality that moves beyond any position that sees either science or theology as a superior form of rational thinking.

The focus on human uniqueness becomes a specific case study in interdisciplinarity. Firstly, Van Huyssteen contextually identifies human uniqueness as a theological problem. Secondly, he applies the contextual approach to paleoanthropology by asking what human uniqueness means in terms of human origins. Against the background of these two steps, he thirdly moves from disciplinary contextuality to a transversal inquiry about the challenges and possible merits of human uniqueness as an interdisciplinary problem.

To the author Darwin's conception of the evolution of human cognition and language, as well as human powers of observation, memory, curiosity, imagination, reason, and moral sense, still functions as the canonical core of the ongoing discourse on human evolution. Paleoanthropology, according to Van Huyssteen, is an umbrella term for the diverse group of sciences contributing to the knowledge of human evolution. At the core of paleoantropology are paleontologists who study human fossils and archaeologists who study the behavioural record of ancient humans. Van Huyssteen argues that evolutionary epistemology helps us to understand that the study of human evolution clarifies the biological preconditions of 
cultural evolution. Although it cannot explain the particular paths that human culture will take through rational knowledge, moral awareness, aesthetic appreciation and religious disposition, it helps us to understand that every human society has possessed a religion of some sort. The prehistory of the human mind points to the naturalness of religion, and supports the broader argument for the rationality and plausibility of religious belief.

Van Huyssteen proceeds to investigate the biblical claim that humans are created in the image of God, because this notion has always been associated in Christian theology with the problem of human uniqueness. He is of the opinion that, in spite of the constantly changing views regarding the meaning of the imago Dei, there is also remarkable continuity, because theologians again and again return to the original biblical text in search for better interpretations. Alone of all creatures, humans are made in the image of God and in that theological sense we are "alone in the world". This could also be said in the paleoanthropological sense of the word since humans are the last of the hominids on this planet.

One of the highlights of the book is the intriguing colour illustrations of some of the most spectacular and earliest material evidence of symbolic behaviour in humans. Fifteen illustrations of Paleolithic cave paintings from France and the Basque Country in northern Spain are given. All these works of art were painted towards the end of the last Ice age (between 40000 and 30000 years ago). These illustrations show the capability of humans to think symbolically and it gives evidence of the earliest forms of religious meaning.

Precisely this symbolic nature of Homo sapiens, according to Van Huyssteen, reveals language as our most distinctive human adaptation, and of crucial importance for our moral and spiritual capacities. Human transcendence is the capacity to exist selfconsciously in the face of discerned possibilities and to respond to situations in the light of what is discerned. Transcendence is what makes us moral, cognitive, and aesthetic agents.

In the light of the above argument, Van Huyssteen concludes that the theological notion of the imago Dei emerged from nature itself. God used natural history for religious belief to emerge as a natural phenomenon. Theology offers a key to understanding the 
vulnerability, tragedy and affliction of our embodied existence, but also the dimensions of hope, redemption and grace.

"Alone in the World?" is an original attempt to scrutinise the interfaces between theology and paleoanthropology. Unfortunately the formulations are sometimes strenuous to read and somewhat "reader unfriendly". This might be the direct consequence of the fact that the publication is actually a reworking of a number of academic lectures. The consequence is that quite a lot is expected of the reader in terms of the background assumed to understand the hermeneutical, philosophical and theological terminology. Nevertheless, it is a very interesting venture into the history of Homo sapiens and it provides an original contemporary attempt to illuminate what it means for humans to exist alone in the world as the imago Dei.

M Murray 